\title{
Parciálne kognitívne funkcie v procese stimulácie čitatel'skej kompetencie žiakov s l'ahkým stupňom mentálneho postihnutia
}

\section{Partial Cognitive Functions in the Process Stimulation of Reading Competence in Students with Mild Intellectual Disabilities}

\author{
Bibiána Hlebová, Prešovská univerzita v Prešove, Prešov
}

\begin{abstract}
Abstrakt
Štúdia sa zaoberá problematikou kognitívnej stimulácie čitatel'skej kompetencie žiakov s l'ahkým stupňom mentálneho postihnutia $v$ mladšom školskom veku, a to so zameraním na rozvíjanie techniky a spôsobu čítania, čítania s porozumením. Štúdia poukazuje na možnosti rozvíjania týchto schopností žiakov s l'ahkým stupňom mentálneho postihnutia, a to na základe stimulácie parciálnych kognitívnych funkcií podla metodiky B. Sindelarovej (2008, T-254 Deficity čiastkových funkcií). Stúdia sa súčasne prikláňa ku kognitívnej edukačnej teórii a potvrdzuje, že aj u žiakov so zníženým intelektom sa môžu rozvíjat' zložité myšlienkové procesy podporujúce rozvoj ich čitatel'skej kompetencie na základe individuálne cielenej stimulácie.
\end{abstract}

\section{Kl'účové slová}

parciálne kognitíune funkcie, čitatel'ská kompetencia, žiak s l'ahkým stupňom mentálneho postihnutia.

\section{Abstract}

Study deals with the issue of cognitive stimulation of reading competence of students with mild degrees of mental disability in younger school age, with a focus on the development of techniques and ways of reading, reading comprehension. The study points to the possibilities of developing these abilities of students with a mild degree of mental disability, based on the stimulation of partial cognitive functions according to the methodology of B. Sindelar (2008, T-254 Deficits of partial functions). At the same time, the study leans towards cognitive educational theory and confirms that even students with reduced intellect can develop complex thought processes that support the development of their reading competence on the basis of individual targeted stimulation.

\section{Keywords}

partial cognitive functions, reading competence, student with mild intellectual disability.

\section{1 Úvod}

Zámer štúdie súvisí s pragmatickým uplatnením inkluzívno-edukačného prístupu vo výchove a vzdelávaní žiakov so špeciálnymi výchovno-vzdelávacími potrebami v pedagogickej praxi na základných školách na Slovensku, ktorý sústred'ujeme na problematiku rozvíjania čitatel'skej kompetencie žiakov s l'ahkým stupňom mentálneho postihnutia (súčast' kurikula predmetu slovenský jazyk a literatúra na základnej škole, ISCED 1, 2016), a to prostredníctvom stimulácie deficitných parciálnych kognitívnych funkcií. V tomto smere považujeme za nevyhnutné, aby učitel' v procese školskej inklúzie týchto žiakov rozvíjal čitatel'skú kompetenciu žiakov čo najcielenejšie a s ohl'adom na aktuálny vývinový stav ich kognitívnych procesov, ktoré do značnej miery predurčujú aj úroveň ich ostatných školských zručností. 


\section{Súčasný stav poznania}

V ostatnom čase sa dostávajú do popredia edukačnej teórie a praxe kognitívne intervenčné prístupy, ktoré odštartovali výskumné práce zástancov dynamického hodnotenia - Feursteina, Tzuriela, Sterberga, Lidzovej, Haywooda (In: Kovalč́́ková, 2010). V dôsledku toho sa predmetom nášho záujmu v poslednom desat́ročí stali kognitívne programy Feursteina (Štrukturálna kognitívna modifikovanost'a skúsenost' sprostredkovaného učenia), Nyborga (Model konceptuálneho vyučovania) a Buckleya (Portsmouthský systém osvojovania si jazykových zručností v ranom veku) (Lebeer, 2006), ktoré boli experimentálne úspešne overované. Autori Feuerstein et al. (2008) zavádzajú pojem štrukturálna kognitívna modifikovanost' (angl. structural cognitive modifitability), ktorým chápu unikátnu prednost' ludského bytia na zmeny a schopnost' adaptovat' sa týmto zmenám mozgu počas životných situácií. Metóda vychádza z teórie štrukturálnej kognitívnej modifikovanosti, skúsenosti sprostredkovaného učenia, dynamického vyšetrenia a inštrumentálneho obohacovania. Títo autori uvedomujúc a rešpektujúc isté limity žiakov so zníženým intelektom v tomto kontexte vypracovali v roku 1957 program FIE (Feuersteinovo inštrumentálne obohatenie) (Feuerstein et al., 2009), ktorý rešpektuje tieto špecifiká a nad’alej stavia na svojej filozofii kognitívnej modifikovanosti. Tento program bol v zahraničí zaradený aj do vyučovania ako samostatný predmet pod názvom Učím sa učit' sa, ktorého úlohou je naplnit́ predpoklady sprostredkovaného vyučovania vo všetkých aspektoch a na základe toho očakávat' zlepšenie intelektového výkonu jedincov. Metóda akceleruje myslenie, zvyšuje efektivitu učenia, učí pracovat' deti s deficitmi, prináša schopnost' vytvorit́ si stratégiu na riešenie úloh, upevňuje sebadôveru, odstraňuje z práce impulzivitu a strach z chyby, neúspechu, rozvíja vyjadrovanie a rešpektovanie iných názorov, pomáha lepšie sa orientovat' vo vlastnom živote, a to pod heslom: „Nechajte ma chvíl’ku, ja si to rozmyslím. "Program FIE je určený detom vo veku od 3 do 8 rokov, ale aj žiakom s problémami v učení či dospelým (Pokorná, 2008).

O skutočnosti, že fenomén kognitívnej stimulácie nie je novým atribútom, svedčia aj vedecké štúdie, ktoré komparujú publikované výsledky s doteraz experimentálne overovanými kognitívnymi programami. Ich primárnym cielom bolo vyzdvihnút' pozitíva aj negatíva daných kognitívnych prístupov s odporúčaniami pre špeciálnopedagogickú prax. Takýto výskumný prístup zohladnil aj Peat et al. (1997), ktorí porovnávali efekt dvoch kognitívnych programov The Strategies Program for Effective Learning/Thinkin a Instrumental Enrichment. Porovnávaním verifikovaných kognitívnych programov sa zaoberali aj Jitendra et al. (2011), ktorí komparovali štúdie prezentujúce výsledky kognitívnej edukácie žiakov s problémami v učení s ciel'om stimulácie čítania s porozumením. Kognitívne stimulačné programy zamerané na učenie sa čítat', prevažne u žiakov s tažkým mentálnym postihnutím, sumarizujú napr. Browder et al. (2006), ktorí prispeli k pohl'adu na to, ako efektívnejšie učiť čítat' tých žiakov, ktorí používajú prevažne nelingvistickú formu komunikácie.

Na základe uvedených štúdií môžeme konštatovat', že kognitívna teória vyvracia zastarané hypotézy, podl'a ktorých žiak so zníženým intelektom nedokáže rozvíjat' zložité myšlienkové procesy a kognitívne funkcie. To potvrdzujú aj d’alší autori: Rolloff (1989, In: Sindelarová, 2008), Perfetti, Lesgold (1977, In: Blachman, 1991), Sindelarová (1996, 2007), Feuerstein et al. (2002, 2008, 2009, 2014), Valenta a kol. (2020). Siegel (2003), Pokorná (2010a, 2010b), Zezulková (2011), Medina (2012), Doidge (2012), Valenta a Petráš a kol. (2012), Žovinec (2014), Žovinec, Krejčová, Pospíšilová (2014), Hlebová, Doord’ovičová (2015), Hlebová, Ďord'ovičová, Palková (2015a, 2015b), Kovalčíková (2017), Hlebová (2020), Valenta a kol. (2020), ktorí zastávajú názor, že poškodenie mozgu, ktoré sa prejaví ako znížený intelekt (podpriemerné IQ) ešte neznamená, že aj kognitívne procesy (pozornost', vnímanie, pamät', myslenie) musia byt' podpriemerné. Naopak zdôrazňujú, že práve parciálne kognitívne funkcie predikujú a ovplyvňujú úspech žiaka v škole viac než intelekt, a to vzhl'adom na to, že klúčová zručnost́ čítania nie je primárne závislá na intelekte, ale na rozvoji kognitívnych funkcií.

Na Slovensku sa podl'a psychodiagnostiky za najkomplexnejšiu diagnosticko-nápravnú metódu považuje metóda T-254 Deficity čiastkových funkcií (Sindelarová, upr. Cerný, 2008), ktorej ciel'om je detailne rozpoznat', v ktorých percepčných a kognitívnych funkciách vykazuje žiak školského veku vývinový deficit. Na základe tohto zistenia je potrebné stanovit́ nápravný individualizovaný program, pretože žiak trpí nie samotným deficitom, ale jeho pôsobením, ktorý sa prejavuje v školských zručnostiach. Metodika poskytuje podrobne rozpracované tréningové materiály pre stimuláciu jednotlivých parciálnych kognitívnych funkcií, pričom rešpektuje postupnost' a nadväznost' kognitívneho vývinu žiaka. 


\section{Parciálne kognitívne funkcie ako metóda stimulácie čitatel'skej kompetencie žiakov s l'ahkým stupňom mentálneho postihnutia}

Problematika skúmania parciálnych (čiastkových) kognitívnych funkcií a školských zručností bola a je stále predmetom záujmu mnohých odborníkov doma i v zahraničí. V tomto kontexte sa už realizovali mnohé výskumy vo väčšine prípadov so žiakmi so špecifickými vývinovými poruchami učenia, napr. u autorov Perfetti, Lesgold (1977, In: Blachman, 1991), Siegel (2003), Roloff (1989, In: Sindelarová, 2008), Stanovich (1986, In: Pokorná, 2010a). Avšak zaznamenali sme aj výskum, ktorý analyzoval auditívnu diferenciáciu ako predpoklad rozvoja komunikačnej kompetencie práve u žiakov s l'ahkým stupňom mentálneho postihnutia (Zezulková, 2011). Na základe výsledkov výskumu autorka dospela k záveru, že lepšiu úroveň v tejto oblasti dosahujú tí žiaci s l'ahkým mentálnym postihnutím, ktorí sú v nej stimulovaní relatívne častejšie. Pričom vyššie hodnoty dosiahli v úlohách, v ktorých je uplatňované konkrétne myslenie (analýza slova na slabiky, syntéza slabík, izolácia prvej hlásky/slabiky, syntéza hlások); nižšie hodnoty dosiahli v úlohách, v ktorých sa prejavujú naplno myšlienkové operácie (produkcia rýmov, analýza slov na hlásky, vynechávanie slabík/hlások). V tomto kontexte musíme konštatovat́ absenciu viacerých zdrojov, ktoré by sa venovali skúmaniu špecifík parciálnych kognitívnych funkcií u žiakov s mentálnym postihnutím v kontexte rozvíjania ich čitatel'skej (aj komunikačnej) kompetencie.

Zvládnutie procesu čítania môžeme opísat' prostredníctvom aktivácie jednotlivých parciálnych funkcií v kognitívnych procesoch (obrázok 1) (Sindelarová, 2008):

1. vydelit' jednotlivé písmená z celkového obrazu napísaného textu - vizuálne členenie (diferenciácia figúry a pozadia);

2. odlíšitt písmená od podobne vyzerajúcich - vizuálna diferenciácia tvarov, priestorová orientácia;

3. správne rozpoznat' a vybavit' jednotlivé tvary písmen - vizuálna pamät';

4. spojitt tvar písmen s ich sluchovou modalitou, teda s hláskou - vytvárat'intermodálne vztáahy;

5. vybavit' si zvuk hlásky (fonémy) - auditívna pamät;

6. tomu predchádza vypočutie hlások, z ktorých sa skladá slovo - auditívne členenie (diferenciácia figúry a pozadia);

7. vzájomne rozlíšit' hlásky (fonémy) - auditívna diferenciácia reči;

8. ak žiak zvládol všetky predchádzajúce úlohy, musí následne vnímat' poradie písmen, aby mohol prečítat' zmysluplné slovo - časová postupnost' (serialita).

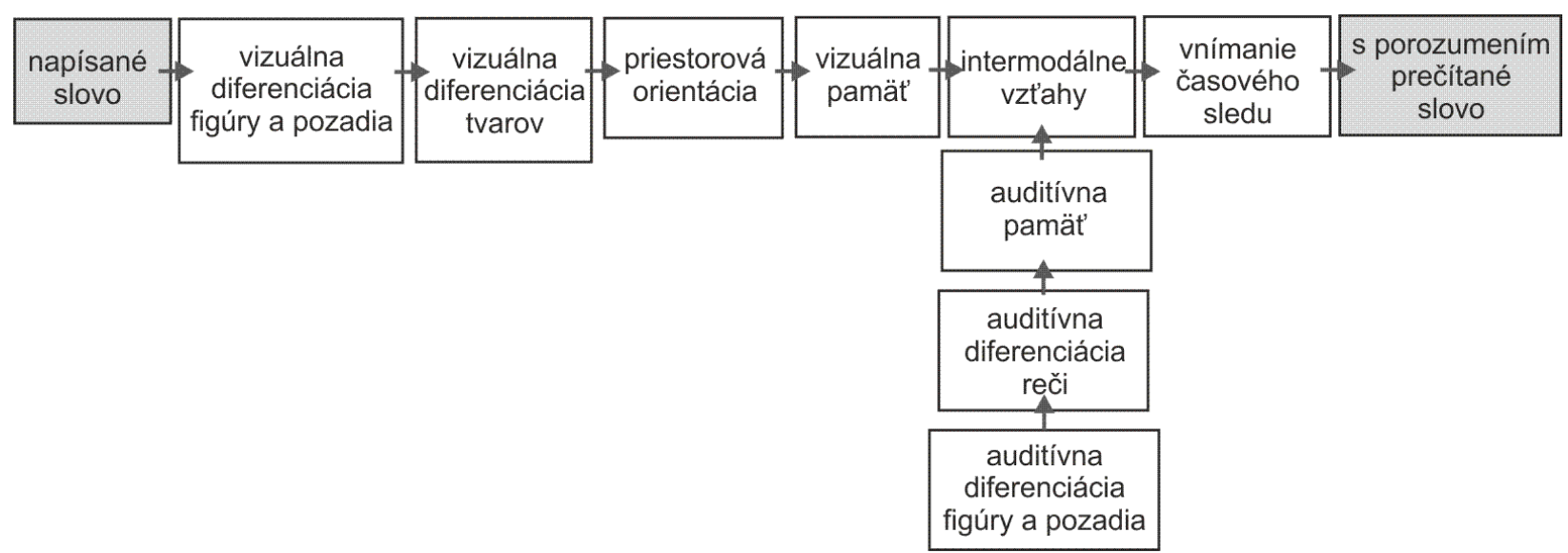

Obrázok 1 Vztáah čitatel'skej kompetencie a parciálnych kognitívnych funkcií (Zdroj: Sindelarová, 2008)

Dôležitost' vizuálnej percepcie (zrakového vnímania) pre neskorší optimálny rozvoj čitatel'skej kompetencie začína už v druhom mesiaci života, kedy sa u diet́at́a objavujú prvé náznaky zrakového kontaktu, a to v čase, ked' zameriava svoju pozornost' na oblast' očí a úst. Zezulková (2011) dodáva, že postupným vývinom táto percepcia garantuje optimálne podmienky pre rozvoj čitatel'skej kompetencie prostredníctvom parciálnych funkcií mozgu, ktorými sú zrakové členenie (diferenciácia figúry a pozadia), zraková diferenciácia, zraková pamät. Jucovičová a Žáčková (2011) uvádzajú, že pre nácvik čítania je dôležité prekonat́ fázu, ktorá je typická pre predškolský vek z hl'adiska optimálneho vývinu, t.j. kedy dieta vníma viac celok ako detaily, pretože pre nácvik čítania je nutné rozlišovat' aj malé detaily, oddelit' podstatné od nepodstatného. Vplyv oslabenia niektorej z parciálnych funkcií v kognitívnej oblasti môže viest' k problémom pri čítaní, ktoré sa prejavia ako (Bednářová, Šmardová, 2007): 
- zámena písmen odlišujúcich sa tvarom (napr. m, n; k, h);

- zámena písmen odlišujúcich sa polohou (napr. d, b; p, b);

- pomalé tempo osvojovania si písmen a ich zapamätávanie, ktoré vedie k pomalému tempu čítania so zvýšenou chybovostou.

Auditívna percepcia (sluchové vnímanie) sa vyvíja už v prenatálnom období, kedy plod vníma zvukové podnety z vonkajšieho a vnútorného prostredia, ktoré sú vtedy modifikované amniovou tekutinou (od 5. mesiaca). Postupným vývinom dozrieva do obdobia, kedy garantuje optimálne podmienky pre rozvoj čitatel'skej kompetencie prostredníctvom čiastkových funkcií mozgu, ku ktorým patrí auditívna členenie (diferenciácia figúry a pozadia), auditíuna difereciácia reči (fonologická analýza), auditívna pamät' (Zezulková, 2011). Stanovich (1986, In: Lechta, 2002) pokladá za prediktor čítania fonologické uvedomovanie, ${ }^{1}$ ktoré spočíva v uvedomovaní si akustickej formy hovorenej reči a schopnosti vyčlenit sluchom slová vo vetách, slabiky v slovách a na vyššej úrovni aj hlásky v slovách, t.j. ich poradie, počet a pod. Oslabenie fonologickej diferenciácie môže významnou mierou ovplyvnit' vývin reči (Bednářová, Šmardová, 2007; Zezulková, 2011). Vplyv oslabenia niektorej z čiastkových kognitívnych funkcií v tejto oblasti sa môže v čítaní prejavit' ako (Bednářová, Šmardová, 2007):

- zložité spájanie písmen do slabík, slabík do slov a orientácia v nich;

- domýšlanie slov;

- zámena podobne znejúcich hlások v slove (b, p; d, t; ž, š);

- zdlihavé osvojovanie si gramatických pravidiel hovorenej reči;

- neporozumenie významu slova;

- namáhavá fixácia správnej výslovnosti hlások;

- využívanie náhradných techník čítania, pričom si žiak slová predčítava, číta častí slova dvakrát aj viackrát za sebou a pod.

Predstavu o usporiadaní priestoru okolo nás získavame pomocou vizuálnych, auditívnych, pohybových, hmatových vnemov a ich kognitívneho spracovania. Oslabenie priestorovej orientácie v procese čítania spôsobuje (Bednářová, Šmardová, 2007):

- stáaženú orientáciu v texte, t.j. sledovanie čítaného textu v správnom smere zl'ava doprava, ako aj

vyhl'adávanie informácií v texte;

- inverziu poradia písmen v texte, čo úzko súvisí s vnímaním časového sledu, vizuálnym vnímaním a lateralitou.

Uhry (1999, In: Lechta, 2002) vyčleňuje d’alšie tri prediktory čítania, a to rýchle súvislé pomenovanie, verbálna krátkodobá pamät', rýchlost'artikulácie.

Úlohu krátkodobej verbálno-akustickej pamäti opísal Lurija (1983, In: Lechta, 2002), ktorú ju nazýva pracovnou pamätou. Jongová (1998) vychádza z predpokladu Siegela (1993), že prevodové pravidlá pre grafémy a fonémy musia byt' podržané v pamäti pri spracovaní jednotlivých častí slova (In: Kulišsták, 2011). Žiaci s l'ahkým stupňom mentálneho postihnutia dekódujú grafémy na fonémy, ale retazce foném nepodržia v pamäti taký čas, aby ich spojili do slov. Ak sa k tomu pridružia aj špecifické asimilácie reči a artikulačná neobratnost' žiakov, je obmedzený celkový proces „pracovného“ zapamätávania, ktorý je determinovaný aj rečou.

Intermodálne vztłahy auditívno-vizuálne, vizuálno-auditívne v procese čítania môžu spôsobovat́ chyby, pri ktorých žiak zamieňa hlásky (b, p), pričom táto chyba nie je dôsledkom vizuálnej diferenciácie či priestorovej orientácie, ale žiak nevie, či vyslovené (b) patrí k tvaru písmena (b) alebo k tvaru písmena (p). Má problém spojit' informácie medzi dvoma zmyslovými oblastami (Sindelarová, 2008). Pokorná (2010b) dodáva, že čítanie s porozumením je zložitý proces, ktorý spočíva v dešifrovaní písaného textu pomocou vizuálnej diferenciácie tvarov, v intermodálnom kódovaní (spojit' písmeno s hláskou), pričom tieto procesy musia prebehnút' v krátkom čase, ktorý si vyžaduje krátkodobá pamät.

Vnímanie časovej postupnosti, seriality v procese čítanie s porozumením zohráva dôležité úlohu. Oslabenie tejto oblasti vedie často k (Bednářová, Šmardová, 2007):

- zámene poradia písmen,

- nesprávnemu usporiadaniu dejovej postupnosti v prečítanom texte,

1Vývin a metódy rozvíjania fonologického uvedomovania u nás prezentovali napr. Mikulajová, Dujčíková(2001), Lechta (2002). Pokorná (2010a) dodáva, že dlhodobé longitidunálne výskumy Libermana, Shankweilera (1989) ukázali, že rozvoj zručnosti fonologického spracovávania ul'ahčuje nácvik čítania. Na základe uvedeného môžeme konštatovat', že žiaci s nedostatočným fonologickým spracovávaním majú sțažený nácvik čítania. 
- zdĺhavému zautomatizovaniu si danej činnosti.

V tomto kontexte je dôležité uvedomit' si, že pri analýze chýb v čítaní môže byt' jedna chyba dôsledkom deficitov viacerých parciálnych kognitívnych funkcií, a teda pre cielenú stimuláciu čitatel'skej kompetencie u žiaka s l'ahkým stupňom mentálneho postihnutia je nevyhnutné rozpoznat' konkrétne deficitnú oblast' v kognitívnych funkciách, ktorú je potrebné následne stimulovat', aby aj daný nedostatok v čitatel'skej kompetencii smeroval k progresu.

\section{Námety na stimuláciu parciálnych kognitívnych funkcií v procese rozvíjania čitatel'skej kompetencie žiakov}

Prezentované námety sú cielene zamerané na stimuláciu parciálnych kognitívnych funkcií (vizuálne členenie, resp. diferenciácia pozadia a figúry; vizuálna diferenciácia tvarov; vizuálna pamät; auditívne členenie, resp. diferenciácia figúry a pozadia; auditívna diferenciácia reči; auditívna pamät; intermodálny vzt́ah;, vnímanie časového sledu; taktilno-kinestetické vnímanie; priestorová orientácia) ako prediktory osvojovania a zvyšovania úrovne čitatel'skej kompetencie žiakov s l'ahkým stupňom mentálneho postihnutia v mladšom školskom veku; sú aplikovatel'né na vyučovacích hodinách slovenského jazyka a literatúry v podmienkach inklúzie na základnej škole (Hlebová, 2020):

- vizuálne členenie (diferenciácia figúry a pozadia) - vyčleňovanie zadaných tvarov písmen na obrázku; vyčleňovanie tvarov písmen, ktoré sú prekrývané čiarami; vyčleňovanie tvarov písmen, ktoré sú písané cez seba; vyčleňovanie zadaných písmen; vyčleňovanie slov, ktoré sú písané cez seba; vyčleňovanie slov na obrázku; vyhl'adávanie pomenovaní objektov na obrázku; prepisovanie pomenovaní objektov podla predlohy; vyhl'adávanie zadaných písmen/slov v rade písmen/slov a pod.;

- vizuálna diferenciácia tvarov - rozlišovanie tvarov (gulaté, hranaté, valcovité, obdĺžnikovité); rozlišovanie rozmerov (malý - vel'ký, nízky - vysoký, krátky - dlhý, úzky - široký, vel'ký - väčší - najväčší a pod.); rozlišovanie písmen, ktoré sa odlišujú detailmi; vyhl'adávanie dvoch zhodných písmen v rade; rozlišovanie inverzných obrázkov, písmen; rozlišovanie podobných písmen, slov; rozlišovanie chýb v slove podl'a predlohy; rozlišovanie chýb v texte podl'a predlohy; hl'adanie dvojíc písmen, slov, ktoré sa od seba odlišujú a pod.;

- vizuálna pamät' - zapamätanie si predmetov, obrázkov, písmen, slov; rozlíšenie predmetov, obrázkov, písmen, slov v rade; umiestnenie obrázkov, písmen, slov na správne miesto podla predlohy; doplnenie slabík, slov podla predlohy; rozlišsovanie predmetov, obrázkov, písmen, slov, ktoré žiak predtým videl a pod.;

- auditívne členenie (diferenciácia figúry a pozadia) - lokalizovanie smeru zvuku; poznanie predmetov podl'a zvuku; opakovanie slov podl'a vzoru so zvukovým pozadím (hlas rádia, ženy, muža, cudzieho jazyka, známych piesní a pod.); fonetické vyčleňovanie zadanej fonémy v slove - na začiatku slova, uprostred slova, na konci slova a jej zapisovanie; diferenciácia zadaného zvuku medzi ostatnými a pod.; - auditívna diferenciácia reči - rozlišovanie druhu zvukov (predmety, zvuky zvierat, hlasy liudí a pod.); rozlišovanie počtu rečových zvukov a ich zapisovanie; rozlišovanie podobných a nepodobných slov a ich zapisovanie; rozvoj sluchovej analýza a syntézy reči (hlások, slabík); rozlišovanie zadaných slov v texte; rozkladanie slov na slabiky; rozlišovanie zadanej predpony v slovách v texte; rozlišovanie slov vo vete; rozlišovanie mäkkých slabík (di, ti, ni, li), tvrdých slabík (dy, ty, ny, ly); rozlišovanie dížky samohlások a spoluhlások; doplňanie spodobujúcich sa písmen do textu na základe počutého príbehu a pod.;

- auditívna pamät' - opakovanie slov vzájomne súvisiacich (na ul'ahčenie zapamätania) a ich zapisovanie; opakovanie slov bez vzájomnej súvislosti a ich zapisovanie; opakovanie viet zložených z troch, štyroch, piatich a viac slov; opakovanie riekaniek, ktorých pravidelný rytmus podporuje zapamätávanie; opakovanie nesúvisiacich slov; zapamätanie zadaných slov a ich rozlišsovanie v skupine počutých slov; doplnenie skupiny slov k danému slovu (na základe počutého vzoru, napr. sliepka = vajce, znášat', kotkodákat'); odpovedanie na otázky na základe počutého príbehu a pod.;

- intermodálne vzt́ahy - vykonanie pohybu na počuté slovo; priradenie slova k obrázku (napr. tento obrázok nakreslil chlapec/dievča); priradenie mien k obrázkom s rôznymi tvárami; priradenie mena (zvieratáa) k melódii, ktorú žiak počuje; priradenie písmen pod čísla tak, aby vzniklo slovo (tajná reč); priradenie písmen pod znaky tak, aby vzniklo slovo (tajná reč) a pod.;

- časová postupnost' (serialita) - zapamätanie si predmetov (obrázky, pexeso) podla určeného poradia; 
určovanie, na ktorom mieste predtým ležal daný predmet; vymenovanie a doplńanie dní v týždni, mesiacov v roku; nacvičovanie číselného radu; doplňovanie desiatok v číselnom rade; doplńanie tvarov do tabul'ky v predpísanom poradí; dopĺňanie čísel a písmen do tabul'ky v predpísanom poradí; prirad'ovanie činností typických pre ráno, predpoludnie, obed, popoludnie, večer; reprodukovanie činností, ktoré prebehli počas dňa, počas hodiny; organizovanie svojich pracovných povinností v časovej postupnosti; rozlišovanie pojmov (skôr, neskôr, najneskôr) v príbehu, komunikačnej situácii; rozlišovanie pojmov (včera, dnes, zajtra, predvčerom, pozajtra) v príbehu, komunikačnej situácii; reprodukovanie série pohybov za sebou; reprodukovanie série pohybov pravej a lavej ruky za sebou; reprodukovanie série pohybov a slov za sebou a pod.;

- taktilno-kinestetické vnímanie - triedenie drobného materiálu hmatom s výpoved’ou a zapisovaním; triedenie hmatom tvarov písmen, čísel, ktoré sa odlišujú povrchom, materiálom s výpoved’ou a zapisovaním; triedenie geometrických tvarov hmatom s výpoved'ou; rozlišovanie predmetov hmatom, ktoré sa odlišujú vel'kost'ou, tvarom, váhou, teplotou s výpoved’ou a zapisovaním; modelovanie geometrických tvarov s výpoved'ou a zapisovaním podl'a predlohy a pod.;

- priestorová orientácia - rozlišovanie pojmov (hore, dole, na, do, v, nižšie, vyššie vpredu, vzadu, pred, za nad, pod, vedl'a, medzi, d’aleko, blízko) na obrázku, v komunikačnej situácii; rozlišovanie pojmov (prvý, posledný, uprostred, prostredný, predposledný) na obrázku, v komunikačnej situácii; rozlišovanie pojmov (hned' pred, hned'za) na obrázku, v komunikačnej situácii; rozlišovanie vpravo, vl'avo na vlastnom tele; opakovanie pohybov pravej a l'avej ruky na vlastnom tele podl'a vzoru; rozlišovanie vpravo, vlavo na umiestnených predmetoch; rozlišovanie a určovanie polohy predmetov na základe dvoch kritérií - vpravo hore; rozlišovanie pojmov vpravo, vl'avo na inej osobe; sledovanie obrázkov zl'ava doprava a ich využitie pri nácviku písania a čítania; orientovanie sa v riadku a využitie pri nácviku písania a čítania; doplňanie slov/písmen/čísiel do obrázka rovnakého vzorca na základe predlohy a využitie pri nácviku písania a čítania; skladanie kociek podl'a stavebného plánu; orientovanie sa vo svojom okolí - žiak vie, ako sa ide do obchodu, do školy a pod.

\section{Diskusia}

Kognitívny prístup v edukácii žiakov s l'ahkým stupňom mentálneho postihnutia sa zaoberá psychickými procesmi ako vnímanie, pamät,́, pozornost', úsudok, rozhodovanie, riešenie problémov a predpokladá, že činnost' organizmu môžeme plne pochopit́ len na základe štúdia psychických procesov, ktoré môžeme objektívne sledovat́ prostredníctvom špecifického vonkajšieho správania, ktoré je však potrebné interpretovat' z hl'adiska tých psychických procesov, ktoré sú ich základom (Nolen-Hoeksema, 2012). Č́tanie je zložitý proces, ktorý sa týka súčinnosti jazyka, pamäti, myslenia, vnímania, pozornosti. Jedna z mnohých teórií predpokladá, že hlavnou príčinou nezvládania čítania u žiakov s l'ahkým stupňom mentálneho postihnutia môže byt' porucha spracovania fonematických informácií, a v dôsledku toho identifikácie slov (Pollatsek a Rayner, 1989, In: Sternberg, 2009).

V štúdii sme prezentovali teoretické východiská o problematike parciálnych kognitívnych funkcií v procese osvojovania čitatel'skej kompetencie, ako aj námety na ich stimuláciu v procese rozvíjania čitatel'skej kompetencie (techniky a spôsobu čítania, porozumenia čítaného textu) žiakov s l'ahkým stupňom mentálneho postihnutia v mladšom školskom veku na vyučovacích hodinách slovenského jazyka a literatúry na základnej škole. V procese edukácie žiakov s l'ahkým stupňom mentálneho postihnutia v podmienkach inklúzie na základnej škole je dôležité, aby učitel' poznal silné stránky žiaka, o ktoré sa môže opierat', aby poznal zákonitosti jeho psychického vývinu, vzájomné súvislosti a korelačné vztahy medzi kognitívnymi funkciami, aby vedel rešpektovat' individuálne tempo vývinu žiaka s l'ahkým stupňom mentálneho postihnutia, ktoré je síce oneskorené, ale prebieha a tým predurčuje jeho učebný potenciál. Na tieto skutočnosti upozorňujú na základe svojich výskumov aj autori ako napr. Doidge (2012), Hlebová, Ďord’ovičová (2015), Hlebová, Dord'ovičová, Palková (2015a, 2015b), Hlebová (2020), Medina (2012), Perfetti, Lesgold (1977, In: Blachman, 1991), Pokorná (2010a), Rolloff (1989, In: Sindelarová, 2008), Siegel (2003) a Stanovich (1986) (In: Pokorná, 2010a), Valenta a Petráš a kol. (2012), Zezulková (2011), Žovinec (2014), Žovinec, Krejčová, Pospíšilová (2014), Valenta a kol. (2020), Hlebová (2020). Zároveň by mal učitel'v procese edukácie zohl'adnit' aj skutočnost', že výkon žiaka s l'ahkým mentálnym postihnutím v školských zručnostiach ovplyvňujú nielen kognitívne funkcie, ale aj sociálne faktory, na čo poukazujú autori ako napr. Metelková, Svobodová, Švrčková (2010), Pokorná (2010b), Zezulková (2011), Valenta, Michalík, Lečbych a kol. (2012). Prínosné 
zistenia v zmysle zvyšovania školskej úspešnosti žiakov prináša aj napr. Blagg (1991), Kozulin (2010), Duchovičová (2011), Babulicová (2012).

\section{Záver}

Čitatel'ská kompetencia je jednou z klúčových kompetencií v primárnom vzdelávaní žiakov podla Vzdelávacieho programu pre žiakov s l'ahkým mentálnym postihnutím (ISCED 1, 2016), a to aj v rámci naplnenia funkčnej a plnohodnotnej školskej inklúzie žiakov s lahkým stupňom mentálneho postihnutia v mladšom školskom veku na základnej škole. Osvojovanie zručnosti správnej techniky a spôsobu čítania, ako aj čítania s porozumením predstavuje kognitívne náročný proces, preto môže týmto žiakom napomôct́t tvorba a aplikácia stimulačného programu podporujúceho deficitné parciálne funkcie mozgu s rešpektovaním individuálnych osobitostí žiakov s l'ahkým stupňom mentálneho postihnutia, a to napr. pri práci s vhodným literárnym textom a obrázkom či obrázkovou knihou.

\section{Literatúra}

Babulicová,Z. (2012). Inkluzívna a kognitívna edukácia a jej implementácia v škole. Dizertačná práca. Nitra: UKF. https://www.pf.ukf.sk/index.php/sk/dokumenty/studenti/docs/obhajobyDP/index.php?option=com_ content\&view=article\&id=347.

Bednářová, J., \& Šmardová, V. (2007). Diagnostika dítěte předškolního věku. Co by dítě mělo umět vo věku od 3 do 6 let. Brno: Computer Press.

Blagg, N. (1991). Can We Teach Intelligence? A Comprehensive Evaluation of Feuerstein's Instrumental Enrichment Program. United States of America: Hillsdale, NJ. ISBN 0-8058-0793-4. http://www.questia.com/library/7872622/can-we-teach-intelligence-a-comprehensive-evaluation.

Blachman, B. A. (1991). Phonological Awareness: Implications for Prereading and Early Reading Instruction. In Brady, S. A., Shankweiler, D. P., \& Liberman, I. Y. Phonological Processes in Literacy: A Tribute to Isabelle Y. Liberma. London: Lawrence Erlbaum associates, publishers, 29-34. ISBN 0-8058-0501X.

http://www.questia.com/library/3680665/phonological-processes-in-literacy-a-tribute-to-isabelle.

Browder, D. M., Wakeman, S. Y., Spooner, F. et al. (2006). Research on Reading Instruction for Individuals with with Significant Cognitive Disabilities. In Exceptional Children [online]. 72 (3).

http://www.questia.com/library/1G1-148480060/research-on-reading-instruction-for-individuals-with.

Doidge, N. (2012). Váš mozek se dokáže změnit. Neuvěřitelné př́běhy osobního vítězstuí díky objevům na poli neurovědy. Brno: CPress. ISBN 978-80-264-0111-7.

Duchovičová, J. a kol. (2011). Vybrané kapitoly z didaktiky pedagogiky a sociálnej pedagogiky. Nitra: PF UKF. ISBN 978-80-8094-857-3.

Feuestein, R., Hoffman, M. B., Falik, L. H. et al. (2002). The dynamic assessment of cognitive modifiability. The learning propensity assessment device: theory, Instruments and techniques. Revised and expanded of the dynamic assessment of retarded performers. Israel: The ICELP press. ISBN 965-90490-0-5.

Feuestein, R., Hoffman, M. B., \& Falik, L. H. (2008). Learning Potential Assessment Device - LPAD Examiner's Manual. Israel: The ICELP press.

Feuestein, R., Hoffman, M. B., \& Falik, L. H. (2009). The Feuerstein Instrumental Enrichment Basic Program. User's Guide. Israel: The ICELP press.

Feuestein, R., Falik, L. et al. (2014). Vytvážení a zvyšování kognitívní modifikovatelnosti. Feuersteinuv program instrumentálního obohacení. Praha: Karolinum. ISBN 978-80-246-2400-6.

Hlebová, B., \& Ďord'ovičová, J. (2015). Rozuíjanie komunikačnej a čitatel'skej kompetencie žiakov s láhkým stupňom mentálneho postihnutia v inklúzii. Prešov: Vydavatel'stvo Prešovskej univerzity. ISBN 97880-555-1356-0.

Hlebová, B., Ďord’ovičová, J., \& Palková, V. (2015a). Kognitívna stimulácia čitatel'skej kompetencie žiakov s láhkým stupňom mentálneho postihnutia v školskej integrácii. Prešov: vydavatel'stvo Prešovskej univerzity. ISBN 978-80-555-1456-7.

Hlebová, B., Ďord'ovičová, J., \& Palková, V. (2015b). Partial cognitive functions in the context of reading competence of the pupils with intellectual disability in the school integration. Prostějov: Computer Media, s. r. o. ISBN 978-80-7402-242-5. 
Hlebová, B. (2020). Parciálne kognitívne funkcie v procese stimulácie komunikačnej kompetencie žiakov s l'ahkým stupňom mentálneho postihnutia. In Mikurčíková, L., Harčaríková, T., \& Scholtzová, I. (2020). Špeciálnopedagogické vedecké a praxeologické problémy v kontexte transformačných procesov. Zborník príspevkov. Prešov: Vydavatel'stvo Prešovskej univerzity, s. 20-45. ISBN 978-80-555-2591-4.

Jitendra, A. K., Burgess, C., \& Gajria, M. (2011). Cognitive Strategy Instruction for Improving Expository Text Comprehension of Students with Learning Disabilities: The Quality of Evidence. In Exceptional Children. 77 (2). http://www.questia.com/library/1G1-247223902/cognitive-strategy-instruction-for-improving-expository.

Jucovičová, D., \& Žáčková, H. (2011). Metody reedukace specifických poruch učení. Praha: Nakladatelství D+H. ISBN 978-80-903869-7-6.

Kovalčíková, I. (2010). Kognitívna stimulácia individuálnych edukačných potrieb žiaka zo sociálne znevýhodneného prostredia. Prešov: Prešovská univerzita v Prešove. ISBN 978-80-555-0197-0.

Kovalčíková, I. (2017). Kognitívna pedagogika 1. Kognitívne determinanty edukačného procesu. Hypotetické, deduktívne a inferenčné myslenie. Prešov: Vydavatel'stvo Prešovskej univerzity. ISBN 978-80-555-1814-5.

Kulišták, P. (2011). Neuropsychologie. Praha: Portál. ISBN 978-80-7367-891-3.

Kozulin, A., Lebeer, J., Madella-Noja, A. et al. (2010). Cognitive modifiability of children with developmental disabilities: A multicentre study using Feuerstein's Instrumental Enrichment-Basic program. In Research in Developmental Disabilities. 31 (2), 551-559. ISSN 08914222. http://www.pulib.sk:2071/ record/display.url?eid.

Lebeer, J. (2006). Programy pro rozvoj myšlení dětí s odchylkami vývoje. Praha: Portál, 2006.

Lechta, V. a kol. (2002). Terapia narušenej komunikačnej schopnosti. Martin: Osveta. ISBN 80-8063-092-5. Lechta, V. (2010). Základy inkluzivní pedagogiky. Praha: Portál. ISBN 978-80-7367-679-7.

Medina, J. (2012). Pravidla mozgu. Nejnovější vědecké poznatky pro úspěch v práci, doma i ve škole. Brno: BizBooks. ISBN 978-80-265-0015-5.

Metelková Svobodová, R., \& Švrčková, M. (2010). Čtenářská gramotnost na 1. stupni ZŠ z pohledu vzdělávacího oboru český jazyk a literatura. Ostrava: Ostravská univerzita v Ostravě. ISBN 978-80-7368-878-3.

Mikulajová, M., \& Dujč́́ková, 0. (2001): Tréning fonematického uvedomovania podlá D. B. El'konina. Metodická príručka. Bratislava: Dialóg. ISBN 80-968502-1-0.

Nolen-Hoeksema, S. et al. (2012). Psychologie Atkinsonové a Hilgarda. Praha: Portál. ISBN 978-80-262-0083-3.

Peat, D., Wilgosh, L., \& Mulcahy, R. (1997). Efficacy of cognitive strategy-based instruction for elementary students with learning disabilities: A retrospective study. In Canadian Journal of School Psychology. 12 (2), 135-142. ISSN 08295735.

http://www.pulib.sk:2071/record/display.url?eid=2s2.00005561470\&origin=resultslist\&sort=plff\&src=s\&st1=\%22Efficacy+of +Cognitive + Strategy\%22\&sid=0FC36F8F5AC8B331BFDC23E4CBF005DAmem16\%3a1.

Pokorná, V. (2008). Programy rozvoje osobnosti Feuersteinovo inštrumentální obohacovaní. Učíme se učit se. 0 metodě. http://www.ucime-se-ucit.cz/0-metode/.

Pokorná, V. (2010a). Teorie a náprava vývojových poruch učení a chovaní. Praha: Portál. ISBN 80-7178-570-9.

Pokorná, V. (2010b). Vývojové poruchy učení v dětstuí a dospělosti. Praha: Portál. ISBN 978-80-7367-773-2.

Siegel, L. S. (2003). Basic Cognitive Processes and Reading Disabilities. In Handbook of Learning Disabilities. New York: Guilford Press. ISBN 1-57230-851-6.

http://www.questia.com/library/117190797/handbook-of-learning-disabilities.

Sindelarová, B. (1996). Předcházíme poruchám učení: soubor cvičení pro děti v předl'kolním roce a v proní tř́dě. Praha: Portál. ISBN 80-7178-736-1.

Sindelarová, B. (2007). Předcházíme poruchám učení: soubor cvičení pro děti v prědškolním roce a v pruní třídě. Praha: Portál. ISBN 978-80-7367-262-1.

Sindelarová, B. (2008). Deficity čiastkových funkcií. Príručka porúch učenia a správania u detí a ich náprava. Bratislava: Psychodianostika.

Sterneberg, R. J. (2009). Kognitivní psychologie. Praha: Portál. ISBN 978-80-7367-638-4.

Valenta, M., Michalík, J., Lečbych, M. a kol. (2012). Mentální postižení v pedagogickém, psychologickém a sociálně-práoním kontextu. Praha: Grada. ISBN 978-80-247-3829-1.

Valenta, M., Morávková Krejčová, L., Hlebová, B. a kol. (2020). Zněvýhodnený žák - deficity dílčích funkcí a oslabení kognitivního výkonu. Praha: Grada. ISBN 978-80-271-0621-9. 
Valenta, M., Petráš, P. a kol. (2012). Metodika práce s dítětem a žákem s mentálním postižením. Olomouc: Univerzita Palackého v Olomouci, Pedagogická fakulta. ISBN 978-80-244-3311-0.http://spc.upol.cz/ profil/wpcontent/uploads/2012/metodiky/MP_Metodika_overovani_web.pdf.

Vzdelávací program pre žiakov s l'ahkým mentálnym postihnutím ISCED 1 - primárne vzdelávanie (2016). Bratislava: MS SR.

http://www.statpedu.sk/sites/default/files/dokumenty/statny-vzdelavaci-program/vp_pre_deti_s_ mentalnym_postihnutim_isced_1.pdf.

Zezulková, E. (2011). Jazyková a komunikatívní kompetence dětí s mentálním postižením. Ostrava: Ostravská univerzita. ISBN 978-80-7368-991-9.

Žovinec, E. (2014). Kognitívne a metakognitívne prístupy k dyslexii - edukácia a poradenstuo. Bratislava: Iris. ISBN 978-80-8153-018-0.

Žovinec, E., Krejčová, L., \& Pospíšilová, Z. (2014). Kognitívne a metakognitíune prístupy k dyslexii - edukácia a poradenstvo. Bratislava: Iris. ISBN 978-80-8153-018-0.

\section{Informácia o autorovi}

doc. PaedDr. Bibiána Hlebová, Ph.D.

Prešovská univerzita v Prešove

Katedra špeciálnej pedagogiky

Ul. 17. novembra 15

08001 Prešov

Slovenská republika

e-mail: bibiana.hlebova@unipo.sk

Vedeckovýskumné zameranie autorky je sústredené na kognitívne aspekty v procese rozvíjania komunikačnej a čitatel'skej kompetencie detí a žiakov s l'ahkým a stredným stupňom mentálneho postihnutia, ako aj detí a žiakov pochádzajúcich zo sociálne znevýhodneného prostredia (najmä z marginalizovaných rómskych komunít). 